\title{
Results of a lymphoblastic leukemia-like chemotherapy program with risk-adapted mediastinal irradiation and stem cell transplantation for adult patients with lymphoblastic lymphoma
}

\author{
Sergio Cortelazzo • Tamara Intermesoli • Elena Oldani • Fabio Ciceri • \\ Giuseppe Rossi • Enrico M. Pogliani • Daniele Mattei • Claudio Romani • \\ Agostino Cortelezzi • Erika Borlenghi • Consuelo Corti • Barbara Peruta • \\ Orietta Spinelli • Alessandro Rambaldi • Renato Bassan
}

Received: 9 March 2011 / Accepted: 2 May 2011 /Published online: 11 May 2011

(C) Springer-Verlag 2011

Sergio Cortelazzo and Renato Bassan contributed equally to the manuscript.

Electronic supplementary material The online version of this article (doi:10.1007/s00277-011-1252-x) contains supplementary material, which is available to authorized users.

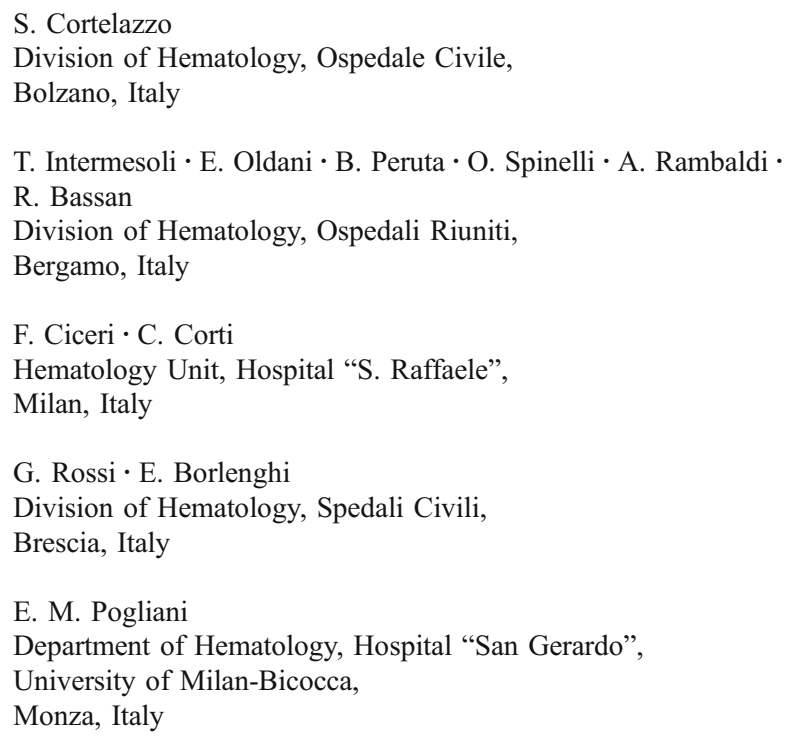

\begin{abstract}
The therapeutic role of mediastinal radiotherapy and stem cell transplantation (SCT) in lymphoblastic lymphoma (LL) remains controversial. In a risk-oriented design, we adopted a flexible treatment program in which (1) patients with persistent mediastinal abnormality, evaluated by post-induction computed chest tomography, received mediastinal irradiation; and (2) those with persistence of minimal residual disease (MRD), evaluated by MRD analysis of the bone marrow, underwent SCT.
\end{abstract}

Twenty-eight out of 30 patients (T-lineage, $n=24$; Blineage, $n=6$ ) achieved a complete response. Of 21 patients with mediastinal mass, $13(62 \%)$ achieved a complete response after chemotherapy alone, while 6 (28.5\%) required additional irradiation. Eleven patients were evaluated for MRD: 6 were negative and 5 positive. On the basis of MRD findings and clinical risk characteristics, 14 patients underwent SCT, 13 received maintenance chemotherapy, and 1 had local radiotherapy. Five patients

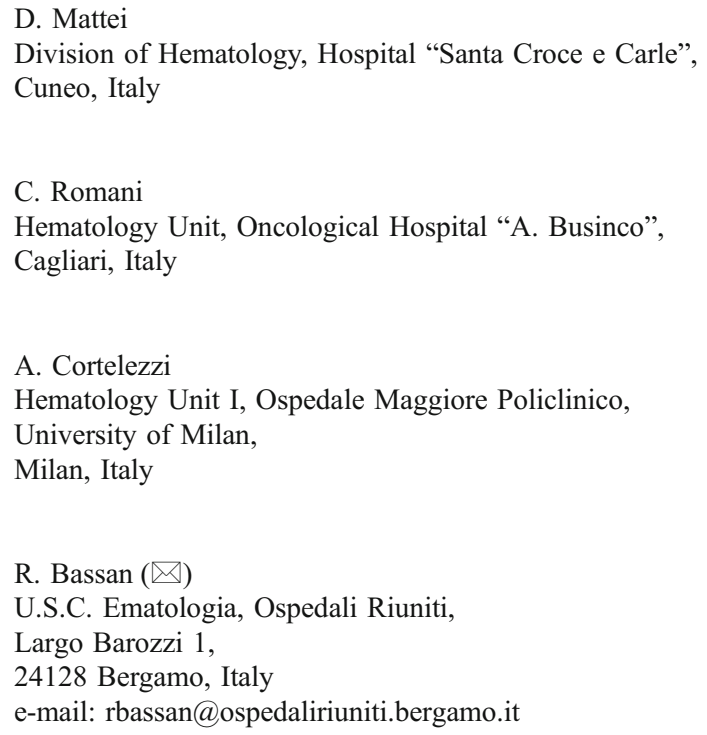


relapsed. Among the 14 non-irradiated patients with T-LL, the mediastinal recurrence rate was only $7 \%$. After a median follow-up of 3.9 years, 21 patients who responded were alive without recurrence (75\%). The projected 5-year survival, disease-free survival, and relapse rate were $72 \%$, $77 \%$, and $18 \%$, respectively. This program induced high remission and survival rates, indicating the feasibility and the benefits potentially associated with a selective, response-oriented policy of mediastinal irradiation and a concurrent MRD-based strategy to assign adult LL patients to SCT.

Keywords Lymphoblastic lymphoma $\cdot$ Mediastinal irradiation $\cdot$ Minimal residual disease $\cdot$ Stem cell transplantation

\section{Introduction}

Lymphoblastic lymphoma (LL) is a rare tumor of B or, more often, $\mathrm{T}$ lymphoblasts that frequently involves the mediastinum (more than $70 \%$ of cases of T-LL). It is related closely to acute lymphoblastic leukemia (ALL), from which it can be differentiated by the predominant extramedullary involvement in LL and bone marrow infiltration by blast cells of less than $25 \%[1,2]$. In adults, LL is treated with regimens that are used to treat ALL (ALL-type regimens) [3-9], but these regimens give inferior results compared with those achieved normally in children [10-12]. One relevant issue is the role of mediastinal tumors in the failure of treatment, and debate persists as to whether all patients should undergo mediastinal irradiation or only those with residual disease post-induction. In a German study, the rate of mediastinal tumor progression was high, despite the use of intensive chemotherapy and early mediastinal irradiation [8]. With the Hyper-CVAD regimen from the M.D. Anderson Cancer Center (MDACC), the use of higherdose irradiation (30-39 Gy) as an adjunct seems to reduce the incidence of relapse, although mediastinal progression still occurs [9]. A second issue related to treatment is whether the identification of prognostic factors, which are used to define patients with high-risk characteristics who are eligible for hematopoietic stem cell transplantation (SCT), can be used to predict outcome. All the risk factors studied so far have failed to predict outcome with respect to current ALL-type chemotherapy regimens [3]. In ALL, the analysis of minimal residual disease (MRD) through immunophenotypic or molecular techniques, which can identify as few as $1 \times 10^{-5}$ leukemic cells in normal-looking bone marrow, provides a powerful means to predict relapse accurately in individual patients [13]. Currently, the intensification of treatment with SCT is considered to be the best treatment option for patients with ALL who are
MRD-positive after induction plus early consolidation therapy. With respect to LL, the prognostic role of MRD has been studied in detail in childhood [14] but not in adult disease. In the present study, we adopted an ALL-type chemotherapy program together with the flexible application of early mediastinal irradiation. Only patients with residual tumors post-induction, as assessed by a computed tomography (CT) scan of the mediastinum, received mediastinal irradiation. MRD in the bone marrow was analyzed concurrently with the mediastinal evaluation to gather evidence of occult disease contamination of the marrow. We used the information obtained as an indicator of the risk of relapse and a tool to decide between postconsolidation maintenance therapy (MRD-negative patients) and SCT (MRD-positive patients).

\section{Patients and methods}

\section{Patients}

Between the years 2000 and 2008, 30 consecutive adult patients with untreated LL were enrolled in the Northern Italy Leukemia Group (NILG) Protocol 09/00 (Table 1) [15]. The diagnosis was established by histological examination in accordance with the WHO criteria $[1,2]$. The clinical evaluation included bone marrow biopsy, the examination of cerebrospinal fluid, a full blood count, and biochemistry, which included serum lactate dehydrogenase, plus CT scans of the chest and abdomen. Clinical staging was performed in accordance with the Ann Arbor System. Because of the difficulty in obtaining adequate diagnostic specimens for a detailed immunophenotypic and cytogenetic/genetic analysis for risk stratification in many LL patients, the high-risk (HR) subset included all the patients with T-LL, those with pro-B CD10-negative B-LL, and those achieving late complete remission (CR). Only the patients with pre-B CD10-positive B-LL were defined standard-risk (SR) in this study.

\section{Analysis of MRD}

Patient-specific molecular probes were identified using biopsy samples or bone marrow in patients with $>5 \%$ infiltrating blast cells, and were tested for sensitivity and specificity as reported previously [15]. One or two probe(s) were used per patient, with the aim of achieving a sensitivity of at least $10^{-4}$ in the RQ-PCR (reverse quantitative polymerase chain reaction) assay. MRD in the bone marrow was examined at baseline and at predefined time points (TP) post-induction (before cycles 4,6 , and 8; i.e., weeks [w] 10, 16, and 22). The MRD findings were entered in an MRD risk model to distinguish between MRD-positive 
Table 1 Diagnostic

characteristics of the patients n.s. not significant

a excluding mediastinum and bone marrow

${ }^{\mathrm{b}}$ one each

*indicates eligibility to SCT by protocol design (modifiable by MRD study)

\begin{tabular}{|c|c|c|c|c|}
\hline Characteristics & Total $(\%)(n=30)$ & B-LL $(n=6)$ & T-LL $(n=24)$ & $P$ value \\
\hline Gender (male/female) & $17 / 13$ & $2 / 4$ & $15 / 9$ & n.s. \\
\hline Age (years), median (range) & $27(16-57)$ & $26(16-28)$ & $32(16-57)$ & 0.04 \\
\hline Hemoglobin $<12(\mathrm{~g} / \mathrm{dL})$, no. $(\%)$ & $5(17)$ & $1(17)$ & $4(17)$ & n.s. \\
\hline Platelets <120 $\left(\times 10^{9} / \mathrm{L}\right)$, no. $(\%)$ & 0 & 0 & 0 & - \\
\hline Elevated LDH, no. (\%) & $18(60)$ & $1(17)$ & $17(71)$ & 0.01 \\
\hline Serum LDH (U/L), median (range) & $530(145-2,787)$ & $298(145-535)$ & $620(266-2,787)$ & 0.006 \\
\hline \multicolumn{5}{|l|}{ Stage, no. $(\%)$} \\
\hline I & $5(17)$ & $3(50)$ & $2(8)$ & \\
\hline II & $8(27)$ & 0 & $8(33)$ & \\
\hline III & $1(3)$ & 0 & $1(4)$ & \\
\hline IV & $16(53)$ & $3(50)$ & $13(54)$ & \\
\hline B symptoms, no. (\%) & $8(27)$ & 0 & $8(33)$ & n.s. \\
\hline Mediastinal involvement, no. (\%) & $21(70)$ & $1(17)$ & $20(83)$ & 0.001 \\
\hline Bone marrow involvement, no. (\%) & $12(40)$ & $2(33)$ & $10(42)$ & n.s. \\
\hline Extranodal involvement, ${ }^{\mathrm{a}}$ no. (\%) & $14(47)$ & $4(67)$ & $10(42)$ & n.s. \\
\hline Pleural effusion & 9 & 0 & $9(37)$ & \\
\hline Pericardial effusion & 3 & 0 & $3(12)$ & \\
\hline Skin & 2 & $2(33)$ & 0 & \\
\hline Ovary/testis & $2^{\mathrm{b}}$ & $2^{\mathrm{b}}(33)$ & 0 & \\
\hline Thyroid & 1 & 0 & $1(4)$ & \\
\hline High risk subset, ${ }^{*}$ no. $(\%)$ & $26(87)$ & $2(33)$ & $24(100)$ & \\
\hline
\end{tabular}

$\left(\mathrm{MRD}^{\text {pos }}\right)$ and MRD-negative $\left(\mathrm{MRD}^{\text {neg }}\right)$ patients $\left(\mathrm{MRD}^{\text {neg }}\right.$, MRD-negative at w22 and negative/low positive $<10^{-4}$ at w16; MRD ${ }^{\text {pos }}$, any other MRD combination).

Early treatment (phase A) and MRD/risk-oriented therapy (phase B)

The NILG Protocol 09/00 (ClinicalTrials.gov identifier: NCT00358072) has been reported previously [15], and is detailed as Online Resource 1. Briefly, the induction plus early consolidation therapy (phase A) consisted of a prednisone-cyclophosphamide pre-phase (T-LL only) [16] followed by eight blocks of chemotherapy administered over 25 weeks, in association with central nervous system (CNS) chemo-radioprophylaxis after cycle 3. Cycles 4 and 7 included high-dose (HD) methotrexate and cytarabine. Autologous blood stem cells that had been primed with GCSF were collected after cycle 4. Mediastinal irradiation (24 Gy planned) was delivered after cycle 2 only to patients with residual disease as confirmed by CT scan $(>2 \mathrm{~cm})$. Post-consolidation therapy (phase B) was MRD/risk-oriented. After completion of MRD analysis, and regardless of clinical risk class, $\mathrm{MRD}^{\text {neg }}$ cases were allocated to standard maintenance therapy, whereas $\mathrm{MRD}^{\text {pos }}$ patients were eligible to allogeneic SCT, or, when a compatible related or family unrelated donor was not found, to autologous HD therapy followed by maintenance. The HD sequence included up to four consecutive "hypercycles" with HD etoposide, 6- mercaptopurine, and melphalan (cycles 1 and 3), and HD methotrexate and cytarabine (cycles 2 and 4), each followed by the reinfusion of $1-2 \times 10^{6} / \mathrm{kg}$ CD $34+$ blood stem cells. The $\mathrm{MRD}^{\text {neg }}$ patients received a 2-year maintenance program with 6-mercaptopurine daily and methotrexate weekly, which was reinforced monthly during the first year by the addition of vincristine-prednisone (even cycles) and cyclophosphamide (odd cycles). Patients for whom the results of MRD analysis were not available were scheduled to receive phase $\mathrm{B}$ therapy on the basis of their clinical risk class (SCT if HR, maintenance if SR).

\section{Response evaluation and statistics}

The response to treatment was evaluated after cycle 1 in accordance with the method of Cheson et al. [17]. This included full clinical assessment, bone marrow biopsy in patients with prior involvement, and CT scans of the chest and abdomen as indicated in the protocol. CR was defined as the disappearance of any clinical manifestation of LL, as confirmed by imaging procedures, which included the recovery of normal marrow morphology (blasts $<5 \%$ ) in patients with infiltrating blast cells. A late CR was characterized by the achievement of a response only after cycle 2 and/or the need for mediastinal irradiation, whereas non-responsiveness indicated the persistence of LL. Overall survival (OS) was calculated from the date of diagnosis to death, and disease-free survival (DFS) from the date of CR 
to relapse at any site or death in CR. The cumulative incidence of relapse (CIR) was calculated from the date of $\mathrm{CR}$ to recurrence. The DFS and survival curves were plotted by the Kaplan-Meier method and compared by the log-rank test.

\section{Results}

Patient characteristics

As shown in Table 1, the median age of the patients was 27 years, 17 patients were male, $80 \%$ had T-LL, and $70 \%$ presented with a mediastinal mass. Infiltration of the bone marrow by LL was documented in $40 \%$, whereas no patient had CNS involvement. After the diagnostic work-up, 13 patients (43\%) were classified as stage I/II $(n=5 / 8)$ and 17 $(57 \%)$ as stage III/IV $(n=1 / 16)$.

Treatment response and mediastinal irradiation

Twenty-eight patients (93\%) achieved CR and 2 had refractory T-LL (Table 2). Of the 21 patients with an enlarged mediastinum, 13 (62\%) entered CR, and 8 (38\%) had a residual tumor as defined by CT scan. Seven of the latter eight patients were irradiated and six achieved CR. All patients who achieved $\mathrm{CR}$ underwent successful collection of blood stem cells (median CD34+ cells $13.3 \times$ $10^{6} / \mathrm{kg}$, range 2-55.3).

\section{Analysis of MRD}

Molecular probes for MRD-based risk definition were identified in 11 of 14 patients studied (Table 3). In 3 patients, no specific probe was detectable, and in 14 other CR patients, no diagnostic specimen was available for probe generation. A molecular probe was obtained successfully in one patient with normal marrow morphology (UPN 289). This finding was not inconsistent with the study methods, because rearrangements of the Tcell receptor gene can be detected with as few as $1 \%$ lymphoblasts [18]. The sensitivity of the probe was $\geq 10^{-4}$ in six patients $(54.5 \%)$. However, given that lowsensitivity probes can be used to detect high levels of MRD, all patients were studied, principally to define those at greater risk of relapse. Interestingly, two of five patients with normal bone marrow on the basis of standard morphological criteria showed a positive PCR signal at baseline (TP0), which indicated subclinical dissemination of tumor cells into the marrow. Eventually, six patients were classified as $\mathrm{MRD}^{\text {neg }}(55 \%)$ and five as $\mathrm{MRD}^{\text {pos }}$ $(45 \%)$. Four of the five $\mathrm{MRD}^{\text {pos }}$ patients were defined as such by the use of low-sensitivity probes, as opposed to only one of the six MRD ${ }^{\text {neg }}$ patients. Autologous blood stem cells collected after cycle 4 were available for MRD analysis in seven patients. Apheretic products were $M R D^{\text {neg }}$ in all three $M R D^{\text {neg }}$ patients, and $M D^{\text {pos }}$ in two of four MRD ${ }^{\text {pos }}$ patients (below quantitative range in one, Table 3).

\section{MRD and risk-oriented therapy}

All six $M R D^{\text {neg }}$ patients received maintenance therapy. Four of the five $\mathrm{MRD}^{\text {pos }}$ patients received SCT, whereas one underwent maintenance therapy owing to the presence of a psychiatric disorder. Among the 17 patients with undefined MRD status, 15 received phase B therapy and 2 did not because of refusal and medical reasons, respectively. Phase B consisted of an allograft or the HD autologous therapy in 9 out of 12 patients classified HR (75\%), and maintenance in 2 of 3 patients classified SR (67\%). Maintenance and HD autologous therapy were instead prescribed to the remaining three HR and one SR patients, respectively, based on patient and/or physician's choice. Eventually, the protocol adherence rate for phase B was $75 \%$ (21 out of 28 patients), in relation to the MRD study results and the clinical risk classification in 10 and 11 patients, respectively.

Table 2 Outcome to induction therapy according to LL subtype, presence of mediastinal mass, and mediastinal irradiation

\begin{tabular}{|c|c|c|c|c|c|c|c|}
\hline \multirow[t]{2}{*}{ Outcome } & \multicolumn{2}{|l|}{ T-LL } & \multicolumn{2}{|l|}{ B-LL } & \multicolumn{3}{|l|}{ ALL } \\
\hline & $\operatorname{Med}+(n=20)$ & $\operatorname{Med}-(n=4)$ & $\operatorname{Med}+(n=1)$ & Med- $-(n=5)$ & $\operatorname{Med}+(n=21)$ & Med- $(n=9)$ & Total $(n=30)$ \\
\hline CR, no. $(\%)$ & $18(90)$ & $4(100)$ & $1(100)$ & $5(100)$ & $19(90.5)$ & $9(100)$ & $28(93)$ \\
\hline After CHT & $13(65)$ & $4(100)$ & 0 & $5(100)$ & $13(62)$ & $9(100)$ & $22(73)$ \\
\hline After CHT plus MRT & $5(25)$ & - & $1(100)$ & - & $6(28.5)$ & - & $6(20)$ \\
\hline Refractory, no. (\%) & $2(10)$ & 0 & 0 & 0 & $2(9.5)$ & 0 & $2(7)$ \\
\hline After CHT & $1(5)$ & - & - & - & $1(4.75)$ & 0 & $1(3.5)$ \\
\hline After CHT plus MRT & $1(5)$ & - & - & - & $1(4.75)$ & 0 & $1(3.5)$ \\
\hline
\end{tabular}

CR complete remission, Med mediastinal mass, CHT chemotherapy, MRT mediastinal radiation therapy (computed tomography-oriented) 
Table 3 MRD study and clinical outcome

\begin{tabular}{|c|c|c|c|c|c|c|c|c|c|c|c|c|c|}
\hline \multirow{2}{*}{$\begin{array}{l}\text { Patient } \\
\text { UPN } \\
\text { (age/sex) }\end{array}$} & \multirow{2}{*}{$\begin{array}{l}\text { Diagnosis }{ }^{\mathrm{a}} \\
\text { (stage) }\end{array}$} & \multirow{2}{*}{$\begin{array}{l}\text { Bone marrow } \\
\text { (\% blast cells) }\end{array}$} & \multicolumn{3}{|c|}{ MRD study } & \multicolumn{5}{|c|}{ MRD study results } & \multirow{2}{*}{$\begin{array}{l}\text { MRD risk } \\
\text { class }\end{array}$} & \multirow[t]{2}{*}{ Treatment } & \multirow[t]{2}{*}{ Outcome } \\
\hline & & & Sample & Probe(s) & $\begin{array}{l}\text { Probe } \\
\text { sensitivity }\end{array}$ & ТP0 & TP1 & TP2 & TP3 & $\mathrm{PB}$ & & & \\
\hline $241(36 / \mathrm{M})$ & T-LL (IV) & Abn (10) & $\mathrm{BM}$ & $\begin{array}{l}\text { TCRD } \\
\text { TCRD }\end{array}$ & $\begin{array}{l}10^{-4} \\
10^{-3}\end{array}$ & $\begin{array}{l}\text { pos } \\
\text { pos }\end{array}$ & $\begin{array}{l}\text { neg } \\
\text { neg }\end{array}$ & $\begin{array}{l}\text { neg } \\
\text { neg }\end{array}$ & $\begin{array}{l}\text { neg } \\
\text { neg }\end{array}$ & NA & $\mathrm{MRD}^{\text {neg }}$ & CHT & $\mathrm{A} / \mathrm{W}(61+)$ \\
\hline 909 (25/M) & T-LL (IV) & Abn (10) & $\mathrm{BM}$ & TCRD & $10^{-5}$ & pos & neg & neg & neg & NA & $\mathrm{MRD}^{\text {neg }}$ & CHT & $\mathrm{A} / \mathrm{W}(21+)$ \\
\hline $57(43 / F)$ & T-LL (I) & $\mathrm{N}$ & Med & TCRD & $10^{-5}$ & NA & neg & neg & neg & neg & $\mathrm{MRD}^{\text {neg }}$ & CHT & $\mathrm{A} / \mathrm{W}(89+)$ \\
\hline $74(36 / F)$ & T-LL (II) & $\mathrm{N}$ & PL & TCRG & $10^{-3}$ & NA & neg & neg & neg & neg & $\mathrm{MRD}^{\text {neg }}$ & CHT & $\mathrm{A} / \mathrm{W}(99+)$ \\
\hline $913(23 / \mathrm{M})$ & T-LL (II) & $\mathrm{N}$ & $\mathrm{LN}$ & $\begin{array}{l}\text { TCRB } \\
\text { TCRB }\end{array}$ & $\begin{array}{l}10^{-4} \\
10^{-3}\end{array}$ & $\begin{array}{l}\text { pos } \\
\text { pos }\end{array}$ & $\begin{array}{l}\text { neg } \\
\text { neg }\end{array}$ & $\begin{array}{l}\text { neg } \\
\text { neg }\end{array}$ & $\begin{array}{l}\text { neg } \\
\text { neg }\end{array}$ & $\begin{array}{l}\text { neg } \\
\text { neg }\end{array}$ & $\mathrm{MRD}^{\text {neg }}$ & CHT & $\mathrm{A} / \mathrm{W}(42+)$ \\
\hline $104(46 / \mathrm{M})$ & T-LL (IV) & Abn (16) & $\mathrm{LN}$ & $\begin{array}{l}\text { TCRG } \\
\text { TCRD }\end{array}$ & $\begin{array}{l}10^{-5} \\
10^{-5}\end{array}$ & $\begin{array}{l}\text { NA } \\
\text { NA }\end{array}$ & $\begin{array}{l}\text { low-pos } \\
\text { low-pos }\end{array}$ & $\begin{array}{l}\text { NA } \\
\text { NA }\end{array}$ & $\begin{array}{l}\text { neg } \\
\text { neg }\end{array}$ & NA & $M_{R D}^{\text {neg }}$ & $\mathrm{CHT}$ & $\mathrm{D}(35,4)^{\mathrm{b}}$ \\
\hline $12(22 / \mathrm{M})$ & T-LL (IV) & Abn (15) & $\mathrm{BM}$ & TCRG & $10^{-3}$ & pos & NA & pos & pos & low-pos* & $\mathrm{MRD}^{\mathrm{pos}}$ & CHT & $\mathrm{A} / \mathrm{W}(112+)$ \\
\hline $331(17 / M)$ & T-LL (IV) & $\mathrm{N}$ & PL & $\begin{array}{l}\text { TCRG } \\
\text { TCRG }\end{array}$ & $\begin{array}{l}10^{-4} \\
10^{-3}\end{array}$ & $\begin{array}{l}\text { NA } \\
\text { NA }\end{array}$ & $\begin{array}{l}\text { NA } \\
\text { NA }\end{array}$ & $\begin{array}{l}\text { pos } \\
\text { neg }\end{array}$ & $\begin{array}{l}\text { neg } \\
\text { neg }\end{array}$ & $\begin{array}{l}\text { pos } \\
\text { neg }\end{array}$ & $\mathrm{MRD}^{\mathrm{pos}}$ & Allo-SCT & $\mathrm{A} / \mathrm{W}(50+)$ \\
\hline $289(30 / \mathrm{M})$ & T-LL (I) & $\mathrm{N}$ & $\mathrm{BM}$ & TCRB & $10^{-3}$ & pos & pos & pos & pos & neg & $\mathrm{MRD}^{\text {pos }}$ & Allo-SCT & $\mathrm{A} / \mathrm{W}(56+)$ \\
\hline 375 (38/F) & T-LL (IV) & Abn (22) & $\mathrm{BM}$ & $\begin{array}{l}\text { TCRG } \\
\text { TCRG }\end{array}$ & $\begin{array}{l}10^{-3} \\
10^{-2}\end{array}$ & $\begin{array}{l}\text { pos } \\
\text { pos }\end{array}$ & $\begin{array}{l}\text { pos } \\
\text { pos }\end{array}$ & $\begin{array}{l}\text { pos } \\
\text { pos }\end{array}$ & $\begin{array}{l}\text { pos } \\
\text { pos }\end{array}$ & NA & $\mathrm{MRD}^{\mathrm{pos}}$ & Allo-SCT & REL/D (19) \\
\hline $22(16 / \mathrm{F})$ & B-LL (IV) & Abn (10) & $\mathrm{BM}$ & TCRG & $10^{-3}$ & pos & NA & pos & pos & neg & $\mathrm{MRD}^{\mathrm{pos}}$ & HD-auto & REL/D (29) \\
\hline
\end{tabular}

$N$ normal, $A b n$ abnormal, $B M$ bone marrow, Med mediastinum, $L N$ lymphnode, $P L$ pleural effusion, $T C R$ T-cell receptor $(B$ beta, $G$ gamma, $D$ delta) gene rearrangement, pos positive $\geq 10^{-4}$, low-pos positive $<10^{-4}$; neg negative, $N A$ not available, $P B$ peripheral blood stem cell harvest $(*$ positivity below quantitative range) $\mathrm{MRD}^{\text {neg }}$, MRD-negative; $\mathrm{MRD}^{\mathrm{pos}}$, MRD-positive, $C H T$ chemotherapy, allo-SCT allogeneic stem cell transplantation, $H D$-auto high-dose therapy ("hypercycles") with autologous support, $A / W$ alive and well in first complete remission, $R E L$ relapse, $D$ death (survival in months)

${ }^{\text {a }}$ T-LL or B-LL

${ }^{\mathrm{b}}$ Patient died of secondary AML

\section{Duration of remission and survival}

With a median follow-up period of 3.9 years (range, $0.8-$ $9.2+$ years), 22 patients (73\%) who responded were alive at the time of writing: 21 in first CR and 1 in second CR. Post-remission failure was due to recurrence $(n=5,18 \%)$ in either the bone marrow (B-LL, $n=1$; T-LL, $n=3$; one irradiated and two non-irradiated patients) or mediastinum ( $n=1$, non-irradiated T-LL patient), or to other malignancy ( $n=2,7 \%$; acute myeloid leukemia [AML] and large B-cell lymphoma, respectively). Of the five patients who relapsed, four died and one is alive in second CR after allogeneic SCT. The estimated OS rate at 5 years was $72 \%, 83 \%$ for B-LL, and $69 \%$ for T-LL. The 5-year DSF rate was $77 \%$, $83 \%$ for B-LL, and $71 \%$ for T-LL; the CIR probability at 5 years was $18 \%$ (Fig. 1).

\section{Prognostic analysis}

The probability of OS and DFS was not affected significantly by any of the factors examined (Table 4). The achievement of a molecular remission was associated with a better outcome; DFS at 5 years increased from $60 \%$ in the $\mathrm{MRD}^{\text {pos }}$ group to $80 \%$ in the $\mathrm{MRD}^{\text {neg }}$ group, although the difference was not statistically significant owing to the small number of patients (Fig. 2). The DFS was $83 \%$ and $81 \%$ in patients who received allogeneic SCT and maintenance therapy, respectively, and $50 \%$ in those who underwent the HD autologous phase. The CIR was $8 \%$ and $17 \%$ in the groups who received maintenance therapy and allogeneic SCT, respectively, compared with $37 \%$ in the group given HD autologous therapy. The outcome of the 11 MRD-studied patients is detailed in Table 3. The outcome of the $12 \mathrm{HR}$ patients treated outside the MRD study varied according to cell subset and treatment. Of the ten T-LL patients, three fared well following allogeneic SCT, six received HD autologous therapy (with one CR death, two relapses, and three patients alive and well), and the last one relapsed after maintenance. Both HR B-LL patients did well on maintenance, and all three SR B-LL patients experienced a prolonged DFS (two maintenance, one HD autologous therapy).

\section{Discussion}

We analyzed the long-term outcome of 30 adult patients with LL who were enrolled prospectively in the NILG study 09/00. LL is rare in adult patients, the most recent prospective series dealing with 27-34 total patients (a 

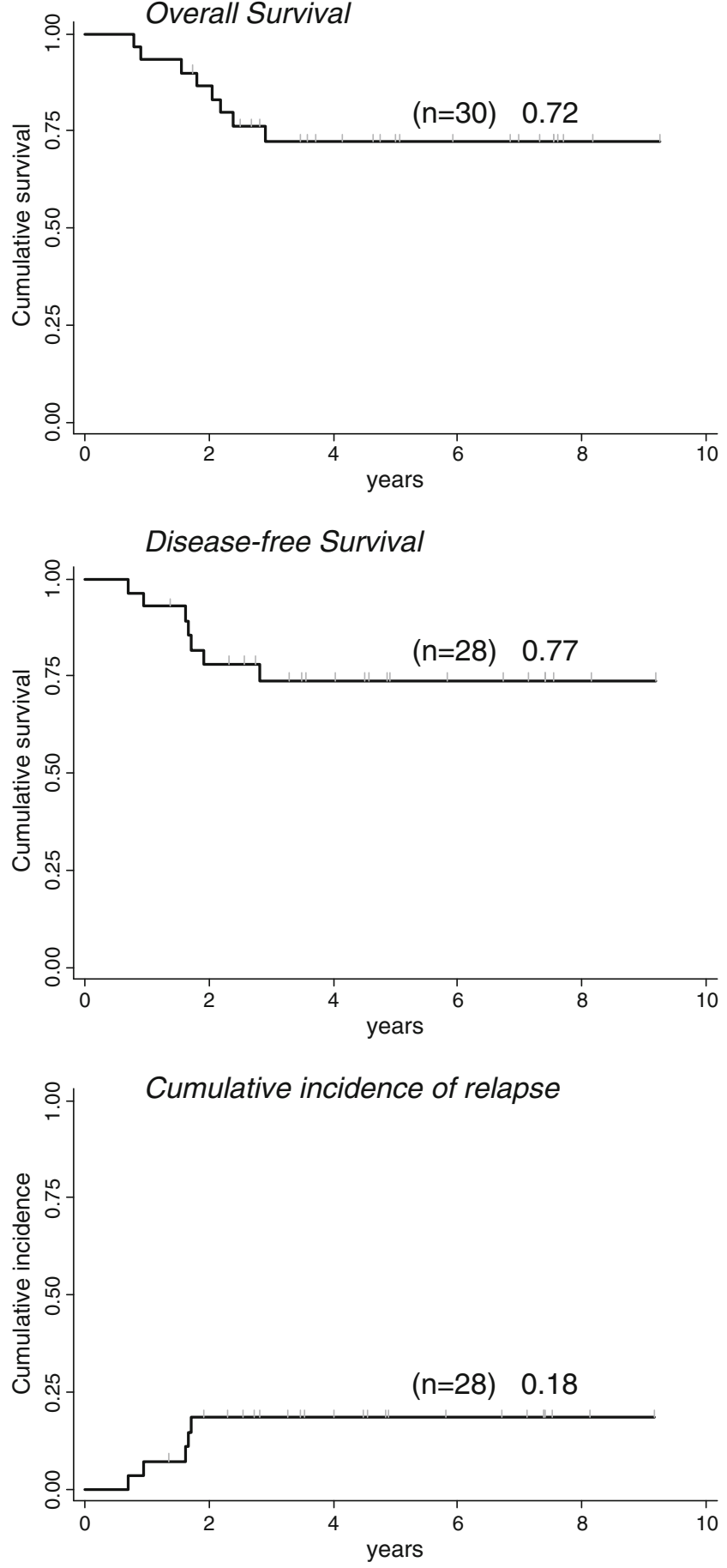

Fig. 1 Kaplan-Meier estimates of overall survival, disease-free survival, and cumulative incidence of relapse (probability at 5 years is indicated)

figure comparable to our study), with only a single study from Germany including exceptionally 45 patients $[8,9,19$, 20]. In the NILG program, induction chemotherapy was integrated with early mediastinal irradiation in patients with suboptimal tumor regression, whereas the molecular analysis of MRD was used for the first time in adult LL to decide between SCT and standard maintenance for postinduction therapy. The general results reflected the high rate of CR that can be attained in LL with ALL-like regimens [4-6, 8-12] in contrast to regimens for non-Hodgkin lymphoma [7, 21].

The rate of $93 \%$ for CR and the projected 5-year OS and DFS rates of $72 \%$ and $77 \%$, respectively, compare favorably with those obtained in recent German and MDACC studies, which reported rates of $91-93 \%$ for CR and 5 -year DFS rates between $62 \%$ and $66 \%[8,9]$. Although ALL-like induction regimens can be associated with pronounced morbidity, none of our patients died early, during induction chemotherapy, as compared with $8 \%$ of patients with ALL who were treated with the same schedule [15]. Two patients (7\%) did die in CR from other neoplasms. Remission mortality in LL has been reported previously to range from $5 \%$ to $9 \%$, which included secondary AML $[8,9]$. The median ages for the patients in the German and MDACC series were 25 and 28 years, respectively, which were similar to the median age in our study (27 years). The distribution of other clinical characteristics was also similar, and no patient in our series had CNS disease, as in the German study but in contrast to the MDACC study (9\%). In the present study, all patients received prophylactic cranial irradiation (18 Gy) plus 12 triple intrathecal injections, and none suffered from CNS relapse. In studies that employed five to eight intrathecal injections with or without cranial irradiation, the rate of CNS relapse was $<5 \%[8,9]$. The lowest rate of CNS relapse $(1.8 \%)$ was observed in one study that employed higher-dose methotrexate $\left(5 \mathrm{~g} / \mathrm{m}^{2}\right.$ instead of $\left.1-1.5 \mathrm{~g} / \mathrm{m}^{2}\right)$ plus intrathecal prophylaxis [22].

In LL, a key therapeutic issue is how mediastinal tumors, which are both the cause and the site of early recurrence, can be managed best [3]. In the current series, 20 out of 24 patients with T-LL (83\%) had mediastinal involvement, but only a proportion of them $(n=8,35 \%)$ had residual disease post-induction, as confirmed by a positive CT scan, that required additional radiation therapy to increase the overall response rate in this patient cohort from $62 \%$ to $82 \%$. Given that mediastinal recurrence occurred in only 1 out of 14 non-irradiated patients in CR (7\%) to confirm the adequacy of the present risk-adapted consolidation regimen (with or without SCT) in patients with chemosensitive mediastinal disease, we recommend the use of selective irradiation on the basis of the early CT result. The omission of mediastinal irradiation in patients who have been identified as responsive to chemotherapy through the CT scan would reduce the delay in the application of chemotherapy, which is theoretically of benefit in patients with extensive extranodal and marrow involvement. Moreover, long-term cardio-pulmonary complications of mediastinal irradiation could be avoided in a significant 
Table 4 Univariate prognostic analysis

\begin{tabular}{|c|c|c|c|c|c|c|}
\hline \multirow[b]{2}{*}{ Prognostic factors } & \multicolumn{3}{|c|}{ Overall survival } & \multicolumn{3}{|c|}{ Disease-free survival } \\
\hline & No. & Probability at 5 years & $P$ value & No. & Probability at 5 years & $P$ value \\
\hline \multicolumn{7}{|l|}{ Age, years } \\
\hline$\geq 30$ & 13 & 0.67 & 0.69 & 12 & 0.73 & 0.88 \\
\hline$<30$ & 17 & 0.75 & & 16 & 0.74 & \\
\hline \multicolumn{7}{|l|}{ Gender } \\
\hline Male & 17 & 0.62 & 0.19 & 15 & 0.63 & 0.26 \\
\hline Female & 13 & 0.85 & & 13 & 0.85 & \\
\hline \multicolumn{7}{|l|}{ Phenotype } \\
\hline B & 6 & 0.83 & 0.49 & 6 & 0.83 & 0.57 \\
\hline $\mathrm{T}$ & 24 & 0.69 & & 22 & 0.71 & \\
\hline \multicolumn{7}{|l|}{ Mediastinum } \\
\hline Not involved & 9 & 0.60 & 0.65 & 9 & 0.60 & 0.54 \\
\hline Involved & 21 & 0.76 & & 19 & 0.79 & \\
\hline \multicolumn{7}{|c|}{ Mediastinum involved } \\
\hline With effusion $^{\mathrm{a}}$ & 9 & 0.89 & 0.29 & 8 & 0.87 & 0.50 \\
\hline Without effusion & 12 & 0.67 & & 11 & 0.73 & \\
\hline \multicolumn{7}{|l|}{ LDH } \\
\hline Normal & 11 & 0.61 & 0.43 & 10 & 0.67 & 0.74 \\
\hline Abnormal & 18 & 0.78 & & 17 & 0.76 & \\
\hline \multicolumn{7}{|l|}{ Clinical stage } \\
\hline I/II & 13 & 0.85 & 0.20 & 13 & 0.77 & 0.81 \\
\hline III/IV & 17 & 0.62 & & 15 & 0.70 & \\
\hline \multicolumn{7}{|l|}{ Bone marrow } \\
\hline Not involved & 18 & 0.83 & 0.13 & 17 & 0.82 & 0.25 \\
\hline Involved & 12 & 0.54 & & 11 & 0.59 & \\
\hline
\end{tabular}

proportion of younger patients, more than $50 \%$ according to our results [23]. To improve this strategy, positron emission tomography (PET) could be used to optimize the evaluation of residual mediastinal disease in T-LL [24] and refine the decision criteria for irradiation. In the German study, 41 out of 45 patients with T-LL (91\%) had mediastinal involvement, and all received radiation therapy at a dose of $24 \mathrm{~Gy}$ [8]. Seven out of 42 patients who achieved CR (17\%) suffered a relapse in the mediastinum. As a result, the radiotherapy dose was increased to 36 Gy in the subsequent trial; the results of which are awaited. Notably, a regimen for childhood LL that avoided irradiation and used a higher dose of methotrexate $\left(5 \mathrm{~g} / \mathrm{m}^{2}\right)$ resulted in a low rate of mediastinal relapse (7\%) [11]. Leukemic T-lymphoblasts are exquisitely sensitive to methotrexate concentrations of approximately $65 \mu \mathrm{mol} / 1$, which are achievable in vivo with $5 \mathrm{~g} / \mathrm{m}^{2}$ methotrexate infusions $[25,26]$. As a consequence, this type of systemic intensification therapy should be evaluated further for the optimal prevention of mediastinal recurrence in T-LL.

Prognostic factors for adult LL are poorly understood. In our series, immunophenotype and clinical stage did not have a significant effect, although survival was slightly better in patients with B- rather than T-LL, as reported previously $[27,28]$, and in patients with stage I/II $(85 \%)$ rather than stage III/IV (62\%) disease. Given that, in patients with ALL, MRD is the best available means to predict relapse and to select high-risk patients for allogeneic SCT [15], we elected to investigate the use of this parameter in adult LL. Up to $30 \%$ of patients with LL are at risk of failing to respond to the chemotherapy regimen used [3]; hence, we looked for persistent signs of MRD in the bone marrow, which denote the chemo-resistant dissemination of LL and an increased risk of relapse. The protocol was designed such that patients who were found to be positive for MRD were switched from standard chemotherapy to allogeneic SCT (or alternatively to HD therapy with autologous stem cell support). Past studies have confirmed the therapeutic efficacy of SCT in adults with LL [19, 29, 30], with survival rates of $55-72 \%$, which almost overlap with the best results obtained with chemotherapy. Although allogeneic SCT might no longer be a routine choice in the current era of improved chemotherapy results $[3,8,9]$, it remains the most effective treatment modality for acute lymphoid malignancies beyond CR1 [31]. Hence, it is appropriate to 

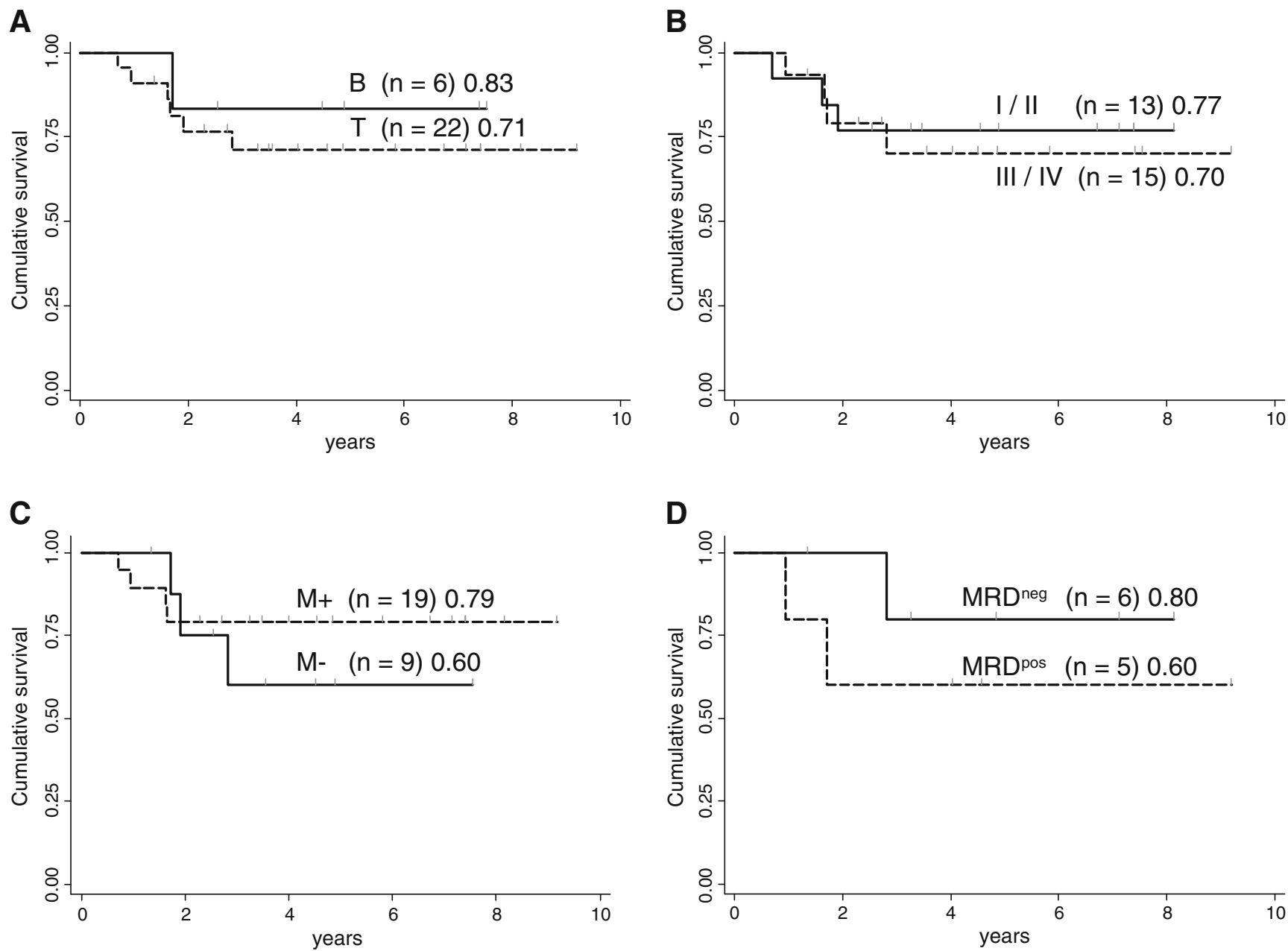

Fig. 2 Kaplan-Meier estimates of disease-free survival according to (a) immunophenotype, (b) clinical stage, (c) mediastinal involvement $(\mathrm{M}+/-$, present/absent), and (d) MRD risk classification (probability at 5 years is indicated)

consider allogeneic SCT in MRD-positive patients, who are at the highest risk of relapse.

Only a small proportion (39\%) of the patients with LL underwent MRD analysis, in contrast to $79 \%$ of the adult patients with ALL who were treated concurrently with the same protocol [15]. In many cases, this can be explained by the lack of an adequate biopsy specimen, together with the low incidence of bone marrow involvement $(40 \%$ of the patients, all with blast cells $<25 \%$ ), which, by itself, precluded the identification and testing of probes. Aside from this, the survival of the MRD ${ }^{\text {neg }}$ patients, who were treated with chemotherapy, was better than that of the $M_{R} D^{\text {pos }}$ patients, whereas MRD ${ }^{\text {pos }}$ patients who received allogeneic SCT fared better than those who were unable to have an allograft. Thus, it appears, in keeping with the rationale of the study, that the analysis of MRD allows the early identification of the relatively few patients with LL who are highly likely to fail chemotherapy, and in whom SCT can have a greater chance of success. In this regard, patients with MRD levels $\geq 10^{-4}$ after early consolidation have the highest risk of recurrence [13, 15]. Low-sensitivity probes $\left(\geq 10^{-3}\right)$, which are unsuitable for the confirmation of a negative status for MRD, are nonetheless useful to detect high levels of residual disease, and should be employed to identify candidates suitable for salvage therapy by SCT. Given that multiparametric flow cytometry allows the degree of marrow contamination by LL cells to be evaluated in almost all patients with a sensitivity of at least $10^{-4}$ [14], this technique should be integrated with, if not substituted for, the molecular analysis of MRD in future studies. The analysis of MRD also confirmed that bone marrow of normal morphology can harbor LL cells at diagnosis. Although this concept is not new [32], and has been emphasized recently in childhood T-LL [14], these findings underline the importance of the analysis of MRD during the diagnostic process. This analysis should increase the accuracy of clinical staging even in patients with earlystage disease and without apparent bone marrow involvement. While SCT was a successful choice in $\mathrm{MRD}^{\text {pos }}$ patients, standard consolidation therapy plus maintenance 
resulted in a high chance of cure (DFS $80 \%$ at 5 years) in the $\mathrm{MRD}^{\text {neg }}$ subset. Extending this observation in a large patient number could also allow to assess the need for prolonged maintenance therapy, that could not be even necessary in T-LL patients who achieve an early mediastinal response and maintain an $\mathrm{MRD}^{\text {neg }}$ status. This perspective should be best evaluated with the support of CT/PET analysis and an optimized MRD monitoring.

The prospective NILG study confirmed the favorable therapeutic outcome of an ALL-type regimen in adults with LL. This treatment, in combination with response-oriented mediastinal irradiation, reduced the incidence of mediastinal recurrence to only $4.5 \%$ ( $1 / 22$ patients with T-LL in CR). Concurrently, the molecular analysis of MRD allowed patients at higher risk of progression to be identified, which both improved the classification of clinical risk and offered the best rationale for the selective application of SCT. The combination of CT/PET scans with flow cytometry analysis of MRD to assess response in the two most critical sites for LL, the mediastinum and bone marrow, could provide another advance in the management of adult LL.

Acknowledgments We are grateful to the following colleagues who contributed to this study: A. Gallamini (Cuneo), E. Angelucci (Cagliari), and K. Aprile (Milan), Italy. The work was supported by grants from AIRC (Associazione Italiana per la Ricerca sul Cancro), Milan, and AIL (Associazione Italiana Leucemia contro le Leucemie) sezione "Paolo Belli", Bergamo, Italy.

\section{References}

1. Brunning RD, Borowitz M, Matutes E, Head D, Flandrin G, Swerdlow SH et al (2001) Precursor B lymphoblastic leukaemia/ lymphoma (precursor B-cell acute lymphoblastic leukaemia). In: Jaffe ES, Harris NL, Stein H, Vardiman JW (eds) Tumours of haematopoietic and lymphoid tissues. IARC Press, Lyon, pp 111114

2. Brunning RD, Borowitz M, Matutes E, Head D, Flandrin G, Swerdlow SH et al (2001) Precursor T lymphoblastic leukaemia/ lymphoma (precursor T-cell acute lymphoblastic leukaemia). In: Jaffe ES, Harris NL, Stein H, Vardiman JW (eds) Tumours of haematopoietic and lymphoid tissues. IARC Press, Lyon, pp 115117

3. Hoelzer D, Gokbuget N (2002) Treatment of lymphoblastic lymphoma in adults. Best Pract Res Clin Haematol 15(4):713-728

4. Slater DE, Mertelsmann R, Koziner B, Higgins C, McKenzie S, Schauer P, Gee T, Straus D, Kempin S, Arlin Z et al (1986) Lymphoblastic lymphoma in adults. J Clin Oncol 4(1):57-67

5. Morel P, Lepage E, Brice P, Dupriez B, D'Agay MF, Fenaux P, Gosselin B, Bauters F, Gisselbrecht C (1992) Prognosis and treatment of lymphoblastic lymphoma in adults: a report on 80 patients. J Clin Oncol 10(7):1078-1085

6. Zinzani PL, Bendandi M, Visani G, Gherlinzoni F, Frezza G, Merla E, Manfroi S, Gozzetti A, Tura S (1996) Adult lymphoblastic lymphoma: clinical features and prognostic factors in 53 patients. Leuk Lymphoma 23(5-6):577-582

7. Bouabdallah R, Xerri L, Bardou VJ, Stoppa AM, Blaise D, Sainty D, Maraninchi D, Gastaut JA (1998) Role of induction chemo- therapy and bone marrow transplantation in adult lymphoblastic lymphoma: a report on 62 patients from a single center. Ann Oncol 9(6):619-625

8. Hoelzer D, Gokbuget N, Digel W, Faak T, Kneba M, Reutzel R, Romejko-Jarosinska J, Zwolinski J, Walewski J (2002) Outcome of adult patients with T-lymphoblastic lymphoma treated according to protocols for acute lymphoblastic leukemia. Blood 99 (12):4379-4385

9. Thomas DA, O'Brien S, Cortes J, Giles FJ, Faderl S, Verstovsek S, Ferrajoli A, Koller C, Beran M, Pierce S, Ha CS, Cabanillas F, Keating MJ, Kantarjian H (2004) Outcome with the hyper-CVAD regimens in lymphoblastic lymphoma. Blood 104(6):1624-1630

10. Neth O, Seidemann K, Jansen P, Mann G, Tiemann M, Ludwig WD, Riehm H, Reiter A (2000) Precursor B-cell lymphoblastic lymphoma in childhood and adolescence: clinical features, treatment, and results in trials NHL-BFM 86 and 90. Med Pediatr Oncol 35(1):20-27

11. Reiter A, Schrappe M, Ludwig WD, Tiemann M, Parwaresch R, Zimmermann M, Schirg E, Henze G, Schellong G, Gadner H, Riehm H (2000) Intensive ALL-type therapy without local radiotherapy provides a $90 \%$ event-free survival for children with T-cell lymphoblastic lymphoma: a BFM group report. Blood 95 (2):416-421

12. Mora J, Filippa DA, Qin J, Wollner N (2003) Lymphoblastic lymphoma of childhood and the LSA2-L2 protocol: the 30-year experience at Memorial-Sloan-Kettering Cancer Center. Cancer 98 (6):1283-1291

13. Bruggemann M, Schrauder A, Raff T, Pfeifer H, Dworzak M, Ottmann OG, Asnafi V, Baruchel A, Bassan R, Benoit Y, Biondi A, Cave H, Dombret H, Fielding AK, Foa R, Gokbuget N, Goldstone AH, Goulden N, Henze G, Hoelzer D, Janka-Schaub GE, Macintyre EA, Pieters R, Rambaldi A, Ribera JM, Schmiegelow K, Spinelli O, Stary J, von Stackelberg A, Kneba M, Schrappe M, van Dongen JJ (2010) Standardized MRD quantification in European ALL trials: proceedings of the Second International Symposium on MRD assessment in Kiel, Germany, 18-20 September 2008. Leukemia 24(3):521-535

14. Coustan-Smith E, Sandlund JT, Perkins SL, Chen H, Chang M, Abromowitch M, Campana D (2009) Minimal disseminated disease in childhood T-cell lymphoblastic lymphoma: a report from the children's oncology group. J Clin Oncol 27(21):35333539

15. Bassan R, Spinelli O, Oldani E, Intermesoli T, Tosi M, Peruta B, Rossi G, Borlenghi E, Pogliani EM, Terruzzi E, Fabris P, Cassibba V, Lambertenghi-Deliliers G, Cortelezzi A, Bosi A, Gianfaldoni G, Ciceri F, Bernardi M, Gallamini A, Mattei D, Di Bona E, Romani C, Scattolin AM, Barbui T, Rambaldi A (2009) Improved risk classification for risk-specific therapy based on the molecular study of minimal residual disease (MRD) in adult acute lymphoblastic leukemia (ALL). Blood 113(18):4153-4162

16. Bassan R, Pogliani E, Lerede T, Fabris P, Rossi G, Morandi S, Casula P, Lambertenghi-Deliliers G, Vespignani M, Izzi T, Coser P, Corneo G, Barbui T (1999) Fractionated cyclophosphamide added to the IVAP regimen (idarubicin-vincristine-L-asparaginase-prednisone) could lower the risk of primary refractory disease in T-lineage but not B-lineage acute lymphoblastic leukemia: first results from a phase II clinical study. Haematologica 84(12):1088-1093

17. Cheson BD, Horning SJ, Coiffier B, Shipp MA, Fisher RI, Connors JM, Lister TA, Vose J, Grillo-Lopez A, Hagenbeek A, Cabanillas F, Klippensten D, Hiddemann W, Castellino R, Harris NL, Armitage JO, Carter W, Hoppe R, Canellos GP (1999) Report of an international workshop to standardize response criteria for non-Hodgkin's lymphomas. NCI Sponsored International Working Group. J Clin Oncol 17(4):1244

18. Langerak AW, Szczepanski T, van der Burg M, Wolvers-Tettero IL, van Dongen JJ (1997) Heteroduplex PCR analysis of 
rearranged $\mathrm{T}$ cell receptor genes for clonality assessment in suspect T cell proliferations. Leukemia 11(12):2192-2199

19. Song KW, Barnett MJ, Gascoyne RD, Chhanabhai M, Forrest DL, Hogge DE, Lavoie JC, Nantel SH, Nevill TJ, Shepherd JD, Smith CA, Sutherland HJ, Toze CL, Voss NJ, Connors JM (2007) Primary therapy for adults with T-cell lymphoblastic lymphoma with hematopoietic stem-cell transplantation results in favorable outcomes. Ann Oncol 18(3):535-540

20. Jabbour E, Koscielny S, Sebban C, Peslin N, Patte C, Gargi T, Biron P, Ferme C, Bourhis JH, Vantelon JM, Arnaud P, Ribrag V (2006) High survival rate with the LMT-89 regimen in lymphoblastic lymphoma (LL), but not in T-cell acute lymphoblastic leukemia (T-ALL). Leukemia 20(5):814-819

21. Le Gouill S, Lepretre S, Briere J, Morel P, Bouabdallah R, Raffoux E, Sebban C, Lepage E, Brice P (2003) Adult lymphoblastic lymphoma: a retrospective analysis of 92 patients under 61 years included in the LNH87/93 trials. Leukemia 17 (11):2220-2224

22. Burkhardt B, Woessmann W, Zimmermann M, Kontny U, Vormoor J, Doerffel W, Mann G, Henze G, Niggli F, Ludwig WD, Janssen D, Riehm H, Schrappe M, Reiter A (2006) Impact of cranial radiotherapy on central nervous system prophylaxis in children and adolescents with central nervous system-negative stage III or IV lymphoblastic lymphoma. J Clin Oncol 24(3):491499

23. Shah AB, Hudson MM, Poquette CA, Luo X, Wilimas JA, Kun LE (1999) Long-term follow-up of patients treated with primary radiotherapy for supradiaphragmatic Hodgkin's disease at St. Jude Children's Research Hospital. Int J Radiat Oncol Biol Phys 44 (4):867-877

24. Weiler-Sagie M, Bushelev O, Epelbaum R, Dann EJ, Haim N, Avivi I, Ben-Barak A, Ben-Arie Y, Bar-Shalom R, Israel O (2010) (18)F-FDG avidity in lymphoma readdressed: a study of 766 patients. J Nucl Med 51(1):25-30

25. Masson E, Relling MV, Synold TW, Liu Q, Schuetz JD, Sandlund JT, Pui CH, Evans WE (1996) Accumulation of methotrexate polyglutamates in lymphoblasts is a determinant of antileukemic effects in vivo. A rationale for high-dose methotrexate. J Clin Invest 97(1):73-80
26. Galpin AJ, Schuetz JD, Masson E, Yanishevski Y, Synold TW, Barredo JC, Pui CH, Relling MV, Evans WE (1997) Differences in folylpolyglutamate synthetase and dihydrofolate reductase expression in human B-lineage versus T-lineage leukemic lymphoblasts: mechanisms for lineage differences in methotrexate polyglutamylation and cytotoxicity. Mol Pharmacol 52(1):155-163

27. Soslow RA, Baergen RN, Warnke RA (1999) B-lineage lymphoblastic lymphoma is a clinicopathologic entity distinct from other histologically similar aggressive lymphomas with blastic morphology. Cancer 85(12):2648-2654

28. Maitra A, McKenna RW, Weinberg AG, Schneider NR, Kroft SH (2001) Precursor B-cell lymphoblastic lymphoma. A study of nine cases lacking blood and bone marrow involvement and review of the literature. Am J Clin Pathol 115(6):868-875

29. Levine JE, Harris RE, Loberiza FR Jr, Armitage JO, Vose JM, Van Besien K, Lazarus HM, Horowitz MM, Bashey A, Bolwell BJ, Burns LJ, Cairo MS, Champlin RE, Freytes CO, Gibson J, Goldstein SC, Laughlin MJ, Lister J, Marks DI, Maziarz RT, Miller AM, Milone GA, Pavlovsky S, Pecora AL, Rizzo JD, Schiller G, Schouten HC, Zhang MJ (2003) A comparison of allogeneic and autologous bone marrow transplantation for lymphoblastic lymphoma. Blood 101(7):2476-2482

30. Sweetenham JW, Santini G, Qian W, Guelfi M, Schmitz N, Simnett S, Nagler A, Holte H, Kvaloy S, Bruzzi P, Goldstone AH (2001) High-dose therapy and autologous stem-cell transplantation versus conventional-dose consolidation/maintenance therapy as postremission therapy for adult patients with lymphoblastic lymphoma: results of a randomized trial of the European Group for Blood and Marrow Transplantation and the United Kingdom Lymphoma Group. J Clin Oncol 19(11):2927-2936

31. Hahn T, Wall D, Camitta B, Davies S, Dillon H, Gaynon P, Larson RA, Parsons S, Seidenfeld J, Weisdorf D, McCarthy PL Jr (2006) The role of cytotoxic therapy with hematopoietic stem cell transplantation in the therapy of acute lymphoblastic leukemia in adults: an evidence-based review. Biol Blood Marrow Transplant 12(1): $1-30$

32. Bradstock KF, Kerr A (1985) Immunological detection of covert leukaemic spread in mediastinal T-cell lymphoblastic lymphoma. Leuk Res 9(7):905-911 